\title{
Proces studiowania realizowany w ramach Programu Erasmus Plus - studium indywidualnych przypadków
}

\section{Wprowadzenie}

W szkolnictwie wyższym dokonują się zmiany, które podążają w kierunku kreowania edukacji akademickiej zorientowanej na studenta i jego proces uczenia się. Program edukacji akademickiej oparty na efektach uczenia się w pierwszej kolejności zaspokaja interesy studentów, a nie interesy kadry akademickiej i uczelni. Podstawowym i najważniejszym efektem kształcenia akademickiego jest umiejętność uczenia się. Wszystkie elementy systemu edukacji akademickiej powinny być nastawione na wspomaganie uczenia się studenta. Proces studiowania jest głównym przedmiotem badań dydaktyki akademickiej.

W warunkach globalizującego się świata proces studiowania pozostaje elementem stałym, natomiast czas, miejsce, formy jego realizacji stają się zmienne. Studiowanie nie jest już prostym procesem, w trakcie którego można zdobyć wystarczającą wiedzę i odpowiednie kwalifikacje zawodowe. Szybki postęp i dezaktualizacja wiedzy zmieniają dotychczasowe zadania edukacji akademickiej, zmieniają też proces studiowania. Zamiast przekazywania konkretnej wiedzy, zmierza się w edukacji akademickiej do kształtowania w młodym człowieku umiejętności ustawicznego uczenia się i gromadzenia doświadczeń.

W tym opracowaniu pragnę przedstawić proces studiowania realizowany przez studentów w ramach Programu Erasmus Plus, 
najpopularniejszego programu wymiany studentów, który obecnie został włączony do programu „Uczenie się przez całe życie”. Mobilność transgraniczna staje się niezwykłą wartością, pozwalającą na zdobywanie doświadczeń niezbędnych w dzisiejszej rzeczywistości, a także przełamywanie barier, umożliwiających otwarcie na świat, inne kultury i ludzi o odmiennych poglądach. Staje się ona szansą na swobodny przepływ myśli i idei oraz kształtowanie tolerancji dla różnorodności przejawów aktywności intelektualnej². Jest również nieodłącznym komponentem budowania europejskiej tożsamości.

\section{Założenia teoretyczne i metodologiczne badań}

Proces studiowania jest złożony i różnie rozumiany. W świetle literatury przedmiotu można określić, że jest to uczenie się w szkole wyższej na danym kierunku, który wiąże się z określoną dyscypliną naukową. Student w tym procesie poznaje język dyscypliny naukowej, przedmiot badań oraz jej warsztat metodologiczny. Program kształcenia na określonym kierunku oparty jest na efektach uczenia się ujętych w trzy zakresy: wiedzy, umiejętności i kompetencji. Proces studiowania obejmuje różnorodne działania studentów, które mają doprowadzić do osiągnięcia przypisanych efektów. Opiera się przede wszystkim na wielostronnej aktywności i samodzielności studentów. Współcześnie nie ma jednego modelu procesu studiowania. Można go analizować w świetle różnych paradygmatów dydaktycznych, które zostały wyróżnione przez A. Sajdak ${ }^{3}$, przyjmując za główne kryterium sposób rozumienia człowieka/w tym przypadku studenta. Przy interpretacji uzyskanych wyników badań odwołuję się do ujęć procesu studiowania w świetle paradygmatów: behawiorystycznego, konstruktywistycznego, humanistycznego i krytyczno-emancypacyjnego.

Celem badań było rozpoznanie przebiegu procesu studiowania w ramach realizacji Programu Erasmus Plus oraz sformułowanie wskazań

$1 \quad$ M. Krajewski, Europejski Obszar Szkolnictwa Wyższego, Wydawnictwo Naukowe Novum, Płock 2004, s. 35.

2 H. Dybiec, Mobilność transgraniczna, BIP, nr 139, marzec 2005, http://www.biuletyn. agh.edu.pl/archiwum_bip/_2005/_139/19_139.html.

3 A. Sajdak, Paradygmaty kształcenia studentów i wspierania rozwoju nauczycieli akademickich. Teoretyczne podstawy dydaktyki akademickiej, Oficyna Wydawnicza „Impuls", Kraków 2013. 
praktycznych skierowanych na doskonalenie studiowania. W badaniach poszukiwano odpowiedzi na następujące problemy badawcze:

1) Jakie motywy zadecydowały o podjęciu decyzji realizacji procesu studiowania w ramach Programu Erasmus Plus?

2) Jak przebiega realizacja procesu studiowania w ramach Programu Erasmus Plus?

W badaniach wykorzystano humanistyczną orientację metodologiczną, a w jej ramach metodę indywidualnych przypadków, technikę wywiadu pogłębionego. Wywiady pogłębione przeprowadzono z 13 studentami uczelni białostockich. Badani studiują w trybie studiów stacjonarnych i reprezentują dwie uczelnie białostockie: Uniwersytet w Białymstoku i Politechnikę Białostocką. Studenci Uniwersytetu w Białymstoku studiują na Wydziałach: Ekonomia i Finanse - 3, Nauk o Edukacji - 3, Filologiczny - 3, Historii i Stosunków Międzynarodowych - 1. Natomiast studenci Politechniki Białostockiej studiują na Wydziałach: Budownictwo - 1, Elektryczny - 1 i Inżynierii Zarządzania - 1.

Humanistyczny model badań dydaktycznych, którego istotą jest zrozumienie i interpretacja pozwala skupić się na punktach widzenia uczestników procesu studiowania, ich codziennych praktykach i wiedzy dotyczącej przedmiotu badań. Proces studiowania jest sytuowany $\mathrm{w}$ kategoriach problemu teoretyczno-praktycznego, gdyż jego duża waga utylitarna skłania do ustawiczności badań przynoszących w zamyśle odkrywanie prawidłowości rozwijających wiedzę teoretyczną i wzbogacających dziedzinę poznania i działania dydaktycznego.

Analiza zebranego materiału empirycznego, redukcja danych pozwoliła wyeksponować główne kategorie pojęciowe: motywy podjęcia decyzji o realizacji procesu studiowania w ramach Programu Erasmus Plus, działania podejmowane przez studentów w procesie studiowania.

\section{Motywy podjęcia decyzji do realizacji procesu studiowania w ramach Programu Erasmus Plus}

W wypowiedziach badanych mocno były eksponowane motywy, które zadecydowały o realizacji procesu studiowania w ramach Programu Erasmus Plus.

Analiza materiału badawczego pozwoliła wyeksponować kilka głównych motywów podjęcia decyzji o realizacji Programu Erasmus Plus (rysunek 1). 


\section{Rysunek 1. Motywy podjęcia decyzji o realizacji programu Erasmus Plus}

Ciekawość poznawcza

Chęć zdobywania nowych doświadczeń

Dążenie do samorozwoju

Chęć podróżowania, poznawania nowych krajów, narodów i ich kultur

Chęć poznawania nowych ludzi, budowanie nowych relacji międzyludzkich

Źródło: wypowiedzi badanych studentów.

Badani w wypowiedziach wskazywali na ciekawość poznawania świata oraz chęć wprowadzenia zmiany w swoim życiu. Motyw poznawczy to czynnik bardzo ważny w podejmowaniu procesu uczenia się/studiowania. Badani nie precyzowali dziedziny rzeczywistości, którą chcieliby poznawać. Wykazywali postawę otwartości na poznawanie świata i zmienianie swojego życia.

- „ „...) wydaje mi się, że czynnikiem decydującym o moim wyjeździe była ciekawość świata i moja wrodzona otwartość na poznawanie innych ludzi" - studentka filologii.

- „O podjęciu takiej decyzji zadecydowała chęć zmiany i poznania czegoś nowego" - studentka filologii.

- „Chciałam wyjechać i zobaczyć coś nowego, coś co nie byłoby mi dane, gdyby nie studia” - studentka Wydziału Nauk o Edukacji.

- „Po części nakłoniła mnie do tego nuda na Politechnice, ale i chęć do zobaczenia i poznania czegoś nowego" - studentka budownictwa.

Innym motywem podjęcia decyzji o realizacji programu Erasmus było zdobywanie nowych doświadczeń podczas studiów. Uczenie się przez zdobywanie doświadczenia ${ }^{4}$ modyfikuje nasze wcześniejsze do-

4 Autorem koncepcji uczenia się przez doświadczenie jest David Kolb, który odwołuje się w niej m.in. do teorii Johna Deweya, Kurta Lewina czy Jeana Piageta. 
świadczenia. Z drugiej strony, nowe doświadczenia mają wpływ na kolejne, z którymi człowiek będzie miał do czynienia w przyszłości.

- „W sumie sam doszedłem do tego, że studia są po to, aby poznawać i doznawać" - student Wydziału Elektrycznego.

- „Zawsze byłam ciekawa nowych rzeczy, to ciekawość ludzkiej natury popchnęła mnie na studia Pedagogiczne. Naprawdę tak wiele zobaczyłam, a wszystko przez moją ciekawość. Mówi się, że ciekawość to pierwszy stopień do piekła, w moim przypadku był to raj (...)" - studentka Wydziału Nauk o Edukacji.

Badani w swoich wypowiedziach wskazywali jako powód wyjazdu na studia w ramach Programu Erasmus Plus chęć podróżowania, poznawania nowych krajów, narodów i ich kultur. Wyraźnie jest to motyw osobisty, nie związany z kierunkiem studiów, ale charakterystyczny dla naszych czasów. Obecność naszego kraju w strukturach Unii Europejskiej stwarza większe możliwości przekraczania granic, a tym samym poznawania świata.

- „Od dziecka chciałam podróżować i dopiero proces studiowania dał mi tą możliwość. Marzenia to piękna rzecz, kiedy możesz je realizować" - studentka ekonomii.

- „od zawsze moim marzeniem było poznawać obce kultury” Studentka filologii.

- „Czemu chciałam wyjechać na Erasmusa? Bo żyję w otwartej Europie, a podróżowanie to moja pasja. Byłam w wielu krajach nie korzystając z żadnego programu. Więc przyszedł czas i na Erasmusa. Wprawdzie jako socjolożka nie miałam dużego wyboru miejsc studiowania, ale jednak coś tam było. Wybrałam Litwę (...). Takie fajne miejsce na badania socjologiczne, nawet $\mathrm{z}$ samego punktu widzenia historycznego (...)" - studentka socjologii.

- „Pomyślałam, że skoro idę na studia to grzechem będzie nie skorzystać z wyjazdu na inną uczelnię. Bo skoro państwo daje nam taką szansę, to warto z niej skorzystać" - studentka Inżynierii Zarządzania.

Badani decydowali się na studia w ramach Programu Erasmus Plus ze względu na chęć własnego rozwoju, dążenie do samorealizacji. Wskazywane motywy podjęcia decyzji uczestniczenia w Programie Erasmus Plus sytuują się w grupie motywów osobowościowych, wewnętrznych. Takie motywy mają szczególne znaczenie w podejmowaniu działań, zaangażowaniu w ich realizację i osiąganiu efektów. 
Przez proces studiowania realizowany w ramach Programu Erasmus Plus studenci widzieli możliwość poznawania nowych ludzi, nawiązywania nowych kontaktów. Te czynniki plasują się w grupie motywów społecznych. Łączą się z dążeniem studentów do kształtowania kompetencji społecznych, które stanowią ważną grupę efektów uczenia się akademickiego.

Analiza wypowiedzi badanych zdobytych podczas wywiadu pokazuje, że studenci podjęli decyzję o realizacji procesu studiowania w ramach Programu Erasmus Plus przede wszystkim z powodów osobistych i społecznych. W wypowiedziach studentów nie pojawiały się motywy związane z kierunkiem studiów, czy też motywy zawodowe.

\section{Przebieg procesu studiowania w ramach realizacji Programu Erasmus Plus}

Badani opowiadając o swoim wyjeździe używali słów: euforia, fascynacja, błogostan, zachwyt. Słowa te dotyczyły głównie momentów pozaakademickich, które dominowały w wypowiedziach badanych.

- „Poza uczelnią, na którą chodziłem dwa razy w tygodniu, podróżowałem ze znajomymi wokół Niemiec. Najistotniejsze dla mojej osoby jednak stało się życie poza uczelnią. Sporo czasu spędziłem na zwiedzaniu. Trzeba było coś robić pomiędzy imprezami a studiowaniem (...)" - student ekonomii.

Badani wśród zajęć pozaprogramowych wymieniali poznawanie nowych kultur, imprezowanie czy zawieranie nowych przyjaźni. Te składniki Programu Erasmus Plus można odnaleźć w każdej wypowiedzi.

- „Na początku, kiedy miałam pierwsze spotkanie na uczelni pomyślałam, że będą to długie godziny spędzone w książkach i nieprzespane noce przed egzaminami. I faktycznie zaliczyłam dużo nieprzespanych nocy, ale ze względu na imprezy i łażenie po klubach. Bo Erasmus to spotykanie innych ludzi z odrębnych kultur, nabieranie umiejętności szerszego myślenia i przede wszystkim zawieranie nowych przyjaźni (...). Po Włoszech jeździ się rowerem, co wspaniale wpłynęło na moją figurę" - studentka filologii.

- „Okres Erasmusa był dla mnie najlepszym przeżyciem, jakiego mogłam doświadczyć. Nie dość, że poznałam inny system edu- 


\section{Rysunek 2. Realizowanie Programu Erasmus Plus w świetle wypowiedzi badanych}
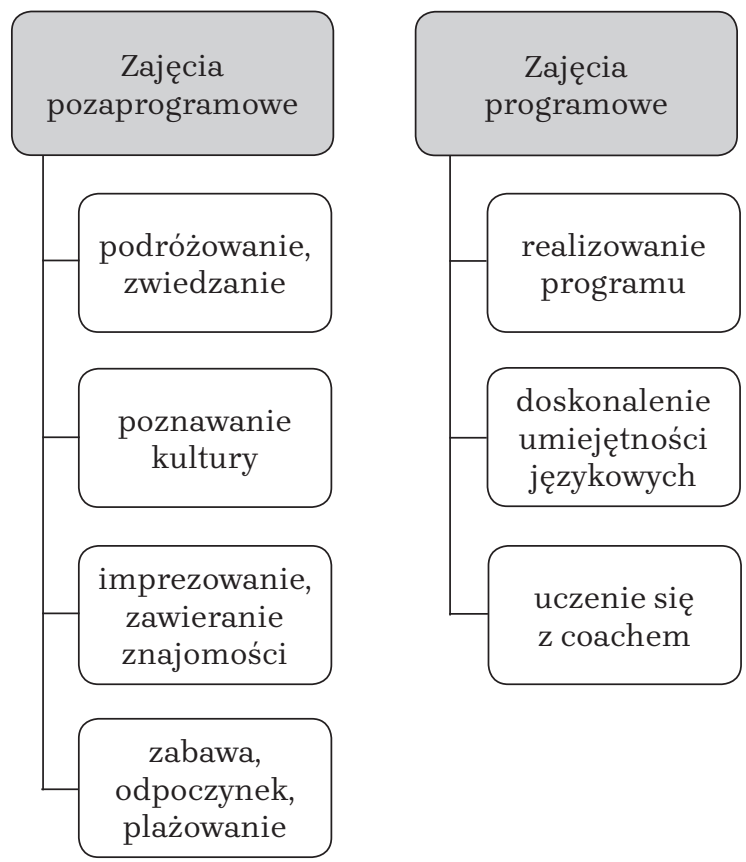

Źródło: wypowiedzi badanych studentów.

kacji, odmienny sposób uczenia oraz zupełnie inne podejście do wielu różnych rzeczy to jeszcze mogłam zwiedzać i imprezować. Same uczenie na Erasmusie nie jest ważne, ponieważ tak naprawdę te przedmioty wcale nie są jakieś wyjątkowe i potrzebne (...). Poznawanie innych ludzi jest ważne. Budowanie nowych znajomości, interakcji i przyjaźni jest ważne" - studentka Wydziału Nauk o Edukacji.

Zajęcia dydaktyczne były realizowane zgodnie z programem, ale w wypowiedziach badanych plasowały się zawsze na dalszym planie.

- „Program Erasmus to naprawdę fajna rzecz. Cieszę się, że ktoś to wymyślił. Mój przebieg studiów, jeżeli chodzi o naukę nie wyglądał imponująco. Miałem kilka godzin w tygodniu zajęć, a reszta to był czas dla mnie. Czasami zdarzało mi się nie iść na poranne zajęcia i nikt nie robił $z$ tego afery, nie to co u nas na Politechnice. Najwięcej zwiedzałem. W którymś tygodniu pierwszego semestru wynajęliśmy ze znajomymi samochód 
i pojechaliśmy zwiedzać Hiszpanię. Naprawdę polecam każdemu. (...) z zaliczeniami nie miałem problemu, wykładowcy mieli bardzo lajtowe podejście do studentów i nie robili żadnych problemów. Jedyne na co poświęciłem więcej czasu to był mój projekt z budownictwa. Do biblioteki nie zaglądałem. Przyznaję się szczerze" - student budownictwa.

- „(...) zwiedzałam, zwiedzałam, zwiedzałam i imprezowałam. Poznawałam, mało się uczyłam na zajęcia. I znowu zwiedzałam. Tak to leciało" - studentka Inżynierii Zarządzania.

Nie każdy z respondentów upatruje w realizacji programu Erasmus tylko rozrywkę. Są osoby, które doszukują się zupełnie innych aspektów wymiany. Takim przykładem jest studentka, która na wymianie była na Litwie:

- „Wszyscy myślą, że Erasmus to ciągłe imprezy, rozrywka i obijanie się. Dla mnie to coś dużo, dużo bardziej głębszego! Jeżeli chodzi o akademicki punkt widzenia, to faktycznie bardzo dużo się nauczyłam, ale ten okres ma jeszcze jeden ważny aspekt, o którym studenci nie mówią. Cały proces studiowania zmienia ludzi. Uczyłam się wielu rzeczy od nowa ze względu na kulturę. Zapisałam się na korepetycje z języka litewskiego. (...) Zwiedziłam bardzo dużo, ale starałam się wyciągnąć jak najwięcej z zajęć, które miałam w planie" - studentka socjologii.

- „(...) Grunt, żeby mieć zaliczone przedmioty(...), w moim wypadku wystarczyło, że chodziłam na zajęcia i pozaliczałam wszystko na piątki. Kiedy wróciłam do Polski miałam średnią prawie 5.0, a znajomi od razu powiedzieli, żebym składała papiery o stypendium" - studentka Inżynierii Zarządzania.

- „Program, który mi przedstawiono na pierwszym wykładzie został w pełni zrealizowany. Wiem, że Erasmus zakłada kilka celów, chociażby takich jak podwyższenie poziomu znajomości języków. Uważam, że jak najbardziej moja uczelnia się z tego wywiązuje. Miałam dodatkowe zajęcia, gdzie mogłam doszlifować mój język angielski i nawet poznać podstawy fińskiego" studentka Wydziału Nauk o Edukacji.

Studenci korzystali z danych im okazji do podniesienia poziomu umiejętności językowych. Bardzo cennym doświadczeniem studentki, która przebywała na Łotwie, było spotkanie z coachem. 
- „Erasmus, jako program stawia sobie wiele różnych celów edukacyjnych, ale i społecznych. Jak najbardziej podstawą jest nauka języka i podnoszenie kompetencji studentów. Uczelnia, na której byłam pomagała Erasmusom na różne sposoby, np. były zajęcia, które miały na celu nauczenie erasmusów języka łotewskiego i angielskiego. Ja skorzystałam z obydwu opcji. Ciekawe były również zajęcia z coachem, który pracował ze studentami na mojej uczelni" - studentka filologii.

Badani mieli też różne doświadczenia dotyczące poznawania celów, które powinny być osiągane w trakcie realizacji programu Erasmus Plus. Jedni dowiadywali się sami o Programie Erasmus Plus, inni zostali uświadomieni przez koordynatorów o celach tego programu. Jednak większość respondentów uważała, że zapoznanie się ze strategią Erasmusa leży w gestii prywatnej każdego, kto planuje wyjazd do obcej uczelni.

Z wypowiedzi badanych wynika, że aktywność studentów koncentrowała się przede wszystkim wokół działań pozaprogramowych. Tego rodzaju aktywność wynikała z motywów, które wymieniali w swoich wypowiedziach, z powodu których podjęli decyzję o realizowaniu procesu studiowania w ramach programu.

O działaniach programowych badani wypowiadali się sporadycznie, przy okazji, traktując je jako drugoplanowe. W tym obszarze studenci realizowali działania zgodnie $\mathrm{z}$ przygotowanym planem. $\mathrm{W}$ tym zakresie nie podejmowali działań z własnej inicjatywy, a mogliby tak czynić chociażby z tego względu, że często mieli wparcie ze strony coacha. W moim odczuciu nie wykorzystali w pełni możliwości, które pojawiały się na wyjeździe. Studenci podczas realizacji programu uczyli się, zdobywali punkty i zaliczali semestr. Większą inicjatywę przejmowali w czasie wolnym, kiedy organizowali rozrywkę i odpoczynek. W wypowiedziach akcentowali, że swój wyjazd na Erasmus spędzili przede wszystkim na odpoczynku, zwiedzaniu i imprezowaniu.

Badani w wypowiedziach eksponowali przede wszystkim zwiedzanie nowych krajów, imprezowanie i zawieranie znajomości. Aspekt akademicki był pokazany na dalszym planie i z reguły pojawiał się dopiero w momencie zaliczenia przedmiotów lub w czasie rozmowy $\mathrm{z}$ rodzicami. 


\section{Podsumowanie}

Analiza zebranych wypowiedzi studentów podczas wywiadu pogłębionego pozwala zauważyć, że badani podejmują decyzję o realizacji procesu studiowania w ramach Programu Erasmus Plus przede wszystkim ze względów osobistych i społecznych. Chcą poznawać świat, nie określając obszarów zainteresowań poznawczych, chcą zmieniać swoje życie, doskonalić siebie. Ważnym motywem podjęcia studiowania w takiej formie było podróżowanie, zwiedzanie wybranego kraju, poznawanie jego kultury. Innym motywem studiowania było poznawanie nowych ludzi, nawiązywanie z nimi kontaktów. Analiza motywów podjęcia studiów w ramach programu pokazuje, że studenci skupiają się na zdobywaniu doświadczenia życiowego, na własnym rozwoju oraz poznawaniu świata. Na dalszym planie plasuje się podejmowanie działań edukacyjnych stricte związanych z programem studiów. Badani nie wskazywali na wiedzę, czy umiejętności dotyczące kierunku studiów.

Analiza działań podejmowanych w procesie studiowania przez badanych pokazuje, że respondenci skupiają się na działaniach pozaprogramowych: podróżowaniu, zwiedzaniu, poznawaniu nowych ludzi, ich kultury, imprezowaniu. Można te działania łączyć z paradygmatem humanistycznym. Działania były podejmowane samodzielnie, z własnej inicjatywy, podczas których badani mogli rozwijać swoje zdolności, możliwości, mogli też korzystać ze wsparcia mentorów. Działania programowe były podejmowane przez badanych w sytuacjach koniecznych, zgodnie z planem, programem. One wiążą się z paradygmatem behawiorystycznym, według którego studenci uczestniczą w planowanych zajęciach, przygotowują się do nich i zaliczają zajęcia zgodnie z ustalonymi kryteriami. Można wnioskować, że badani w zakresie działań programowych byli mało samodzielni, zaangażowani. Zajęcia programowe traktowali jako sprawę drugoplanową.

Badani studenci przypisywali liczne walory realizowanemu programowi, do których zaliczali dobrą zabawę, dobre towarzystwo, zwiedzanie, imprezowanie. Nie wymieniali walorów dotyczących działań edukacyjnych.

Reasumując, badania pokazują, że w ramach Programu Erasmus Plus mało jest studiowania określonej dyscypliny naukowej. Studenci 
nie są świadomi osiągania efektów uczenia się w ramach programu studiów, trudno ocenić, czy są one osiągane.

Z badań wynika konieczność zwrócenia większej uwagi w procesie studiowania w ramach Programu Erasmus Plus na działania, które będą prowadziły do zdobywania wiedzy, umiejętności czy kompetencji z zakresu studiowanej dyscypliny.

Z pewnością ogromną wartością jest osiąganie dorosłości, samodzielności, zaradności życiowej poprzez realizację programu, ale nie mniej ważne jest osiąganie efektów uczenia się z zakresu studiowanej dyscypliny naukowej.

Wydaje mi się, że warto byłoby podnieść wymagania stawiane przy rekrutacji do uczestnictwa w Programie Plus, aby korzystali z tego programu studenci najlepsi. Przyjęcie studentów do realizacji Programu Erasmus Plus powinno stanowić nagrodę. Konieczne staje się przygotowanie studentów do świadomego i aktywnego studiowania dyscypliny w ramach programu. Warto zastanowić się nad weryfikacją efektów uczenia się osiąganych w ramach realizowanego programu.

\begin{abstract}
The article presents a report on qualitative research related to the study process under the Erasmus Plus Program. The motives for making the decision to study in this way and the actions taken by students were highlighted.

The analysis of the process of studying of the respondents allowed us to formulate several practical guidelines aimed at improving the process.
\end{abstract}

\title{
Bibliografia
}

Krajewski M., Europejski Obszar Szkolnictwa Wyższego, Wydawnictwo Naukowe Novum, Płock 2004.

Sajdak A., Paradygmaty kształcenia studentów i wspierania rozwoju nauczycieli akademickich. Teoretyczne podstawy dydaktyki akademickiej, Oficyna Wydawnicza „Impuls”, Kraków 2013.

\section{Netografia}

Dybiec H., Mobilność transgraniczna, BIP, nr 139, marzec 2005, http:// www.biuletyn.agh.edu.pl/archiwum_bip/_2005/_139/19_139.html. 